\title{
Can males of Nyctalus noctula successfully mate in their first year?
}

\author{
Eugenia I. KOZHURINA and Peter N. MOROZOV
}

\begin{abstract}
Kozhurina E. I. and Morozov P. N. 1994. Can males of Nyctalus noctula successfully mate in their first year? Acta theriol. 39: 93-97.

Young males of Nyctalus noctula (Schreber, 1774) are known to remain immature in the year of their birth in some parts of the species range, but reach maturity in other parts. In the latter case, however, a doubt has been expresses about whether they would be able to mate. We adduce strong evidence that males of the year can really be fertile. In captive noctules, among which there were no old males, copulatory behaviour and parturition were observed. The possible significance of this phenomenon is discussed.
\end{abstract}

Institute of Evolutionary Morphology and Ecology of Animals, Russian Acad. Sci., Leninsky prosp. 33, Moscow 117071, Russia

Key words: Nuctalus noctula, reproduction, maturity of males

\section{Introduction}

For a long time it has been an accepted view that males of Nyctalus noctula (Schreber, 1774) as well as of many other microchiropteran species attain sexual maturity only in the second year of their life (Cranbrook and Barrett 1965, Kleiman and Racey 1969, Pan'utin 1970). Even having found spermatozoa in epididymides of 4-month-old males of this species in Czechoslovakia, Gaisler et al. (1979) considered it probable that yearling males, though mostly sexually mature, are not included in reproduction because of small size of their testes and accessory glands.

We did not undertake any special research on this subject, and it was by pure chance that we got substantial evidence of fertility of young male noctules. As observations like ours are exceptionally rare and, at the same time, imortant for understanding many aspects of bat biology, they are worth reporting about and discussing.

\section{Materials and methods}

The noctules captured are listed in Table 1.

Sample I was obtained as a whole nursery group from a hollow tree close to the experimental station Tchernogolovka ( $56^{\circ} 02^{\prime} \mathrm{N}, 38^{\circ} 27^{\prime} \mathrm{E}$, near Moscow) of Severtsov Institute of Evolutionary 
Table 1. Sampling data of Nyctalus noctula.

\begin{tabular}{|c|c|c|c|c|c|}
\hline \multirow{2}{*}{ Sample } & \multirow{2}{*}{$\begin{array}{l}\text { Date of } \\
\text { capture }\end{array}$} & \multicolumn{3}{|c|}{ Composition of samples } & \multirow{2}{*}{ Total } \\
\hline & & adult females & young females & young males & \\
\hline I & 2 Aug 1990 & 7 & 4 & 12 & 23 \\
\hline \multirow[t]{4}{*}{ II } & 6 Aug 1990 & - & - & 4 & \\
\hline & 14 Aug 1990 & - & 1 & 1 & \\
\hline & 16 Aug 1990 & 2 & 2 & 2 & \\
\hline & 17 Aug 1990 & - & 4 & 1 & 17 \\
\hline \multirow[t]{4}{*}{ III } & 3 Aug 1991 & 1 & 2 & 2 & \\
\hline & 4 Aug 1991 & - & - & 2 & \\
\hline & 5 Aug 1991 & 1 & - & - & \\
\hline & 21 Aug 1991 & - & 2 & - & 10 \\
\hline Total & & 11 & 15 & 24 & 50 \\
\hline
\end{tabular}

Morphology and Ecology of Animals. At the station they might occupy up to four available woden boxes $(18 \times 20 \times 38 \mathrm{~cm})$ of their own choice. The boxes were installed side by side on the wall of an observation house. Boxes had back walls made of plexiglass to enable us to observe and identify bats by their individual artificial marks, and exit holes to enable bats to fly out into an outdoor encbsure $(25 \times 12 \times 6 \times \mathrm{m})$. Judging by the patterns of interactions among individuals, there were five lactating females with two pups each, two with singletons, and four independent young in the group. Th: last nursing was recorded on 16 August 1990.

The bats included in sample II were caught one by one with a mist net near the enclosure to vhich they were attracted by calls of the captive noctules. Both adult females of that sample had their nipples suckled out. On 20 August 1990 a combined group consisting of 16 individuals from sanple I ( 4 adult females, 2 young females and 10 young males) and 9 (2, 4 and 3, respectively) from sample II was formed by us to be retained further in captivity. In mid-October 1990, 25 bats of that rroup (one male from sample II died) were transferred to a winter quarter where the temperature was maintained at $12^{\circ} \mathrm{C}$. Under those conditions noctules continued to feed, although they were torpd for the most of the day. After lowering the indoor temerature to $4^{\circ} \mathrm{C}$ at the beginning of December, bats stopped feeding altogether. Only 4 old females, 2 young females and 2 young males lived till sunmer 1991 and were returned to the enclosure.

Bats of sample III were captured in the same way as sample II and relased afterwards, except one male. Mammary glands of the two adult females were also suckled out.

All the animals of three samples mentioned above were measured and externally examinedupon the capture. The main criterion for recognizing young noctules, at least in August when we cuught them, was absolutely unworn teeth and transparent, as if of glass, tips of the canines. They were no longer juveniles because they had reached adult dimensions (Racey 1974, Gaisler et al. 1979; the mean forearm length of young females $(x=54.6 \mathrm{~mm}, \mathrm{SD}=1.48 \mathrm{~mm}, n=15)$ and young males $(53.9$ $\pm 1.23 \mathrm{~mm}, n=24)$ differed from that of adult females $(53.4 \pm 1.35 \mathrm{~mm}, n=11)$ nonsignificantl $(t=$ 2.064 and $t=2.030$, respectively, $p>0.05$, Student's $t$-test). Hence they could be rather classifid as yearlings after Gaisler et al. (1979). Observations on behaviour of roosting bats were carried at in August 1990 almost daily, and in September-November that year only episodically. 


\section{Results}

\section{Reproductive condition of young males in August}

In 10 young males from sample I as well as in all males from samples II and III the caudal edge of testes lay visibly lower than the tip of the penis. In one male from sample I only one testicle reached this border, and in other male, which was not a litter-mate of the former, both testes were situated still high.

All males captured in August 1990 and 1991 had more or less swollen testes. By eye, the size of testes did not exceed $5 \times 3 \mathrm{~mm}$; however, in one male trapped on 4 August 1991 testes were large, approximately $8 \times 5 \mathrm{~mm}$. None of the young males was with distended caudae epididymides. In mid-August 1991 two captive overwintering males had testes of $7 \times 3$ and $10 \times 6 \mathrm{~mm}$ but showed no epididymal enlargement either.

\section{Copulatory behaviour of young males}

At 23.00 of 26 September 1990 we observed in one of the boxes a male (from sample I) which sequentially mounted young and old females including his mother. We can not say with certainty whether those copulations were completed. Since parturitions in noctules near Moscow commence usually in early June and sometimes even in late May (our data) the age of the sexually active male was evaluated as 4 months or somewhat less. From mid-October till early December 1990 some other copulations were noticed in bats at hibernaculum.

\section{Parturition}

One of six overwintering females gave birth to viable male twins on 27 June 1991. It was an old female from sample II captured on 16 August 1990.

\section{Discussion}

Although the overhelming majority of the adolescent male noctules had by early-mid-August apparently smaller and higher situated testes than adult males could have at that time, a certain extent of testicular enlargement suggested that in those young spermatogenesis was in progress. The differences in sexual development of the August-caught young males could be associated with different dates of the birth and/or with individual peculiarities of the animals. At least the latter appears to be very likely as one son of a female from the nursery group had both testes in the low position, and the other had only one completely descended testis. Speakman and Racey (1986) have revealed in Plecotus auritus that the state of sexual development of males depends on their body condition and varies significantly between roosts. The latter factor, however, may not be of great importance to noctules since throughout the summer intermixing of nursery groups occurs within a local population (Sluiter and van Heerdt 1966, Pan'utin 1970).

Occurrence of copulating behaviour in male noctules in their first autumn indicates that the early attainment of sexual maturity is adaptive, in the sense 
that it is directed at the possible participation of young males in breeding. This conclusion is confirmed by the fact that one of the captive females successfully gave birth. The female was able to mate with only males of the year because at that time we had no old males at all. It is doubtful that this female had been inseminated before capture, i.e. before 16 August. Firstly, in different regions (Great Britain, the Netherlands, Germany) the mating season is known to commence at similar time, on the last days of August or in early-mid-September (Sluiter and van Heerdt 1966, Kleiman and Racey 1969, Howes 1979, Kronwitter 1988). In southern Switzerland mating starts, perhaps, earlier, as the first "songs" of territorial males were recorded there on 13 August (Zingg 1988). But it should be noted that one of two "our" overwintering males "sang" sporadically all over the summer since early June 1991. Secondly, in the Czech population where the reproductive pattern is similar to that in the central European part of Russia, oestrus commences in females and epididymides are distended with spermatozoa by the end of August (Gaisler et al. 1979).

Copulation of a 5-month-old noctule during hibernation has been registered by Gebhard (1991), at the observation station "Hofmatt" in Switzerland. Some copulations of captive 6-month-old male and female of Pipistrellus pipistrellus from Mediterranean population have also been desribed (Kunkel and Taake 1986). At the same time, under laboratory maintenance of noctules from the most western, British, population young males showed neither mating behaviour nor anlargement of the testes (Kleiman and Racey 1969). Cranbrook and Barret (1965) did not notice any swelling of the testes of the August-caught young males from Britain either. On the one hand, these facts suggest that the keeping of animals in captivity, on its own, may not stimulate or inhabit the sexual development. On the other hand, the same facts imply existence of population differences in the rate of male pubescence.

Our observations are consistent with a trend of the increase in fecundity of $N$. noctula from the west to the east of the species range (Gaisler et al. 1979). The early sexual maturing of male bats as well as the higher fecundity may be considered one of the many mechanisms compensating higher mortality rate (Read and Harvey 1989). It is symptomatic that the microchiropteran species for which the early attainment of maturity by males is known (see review for 11 species by Tuttle and Stevenson 1982; and also for Taphozous longimanus - Krishna and Dominic 1983; Coleura afra - McWilliam 1987b; Myotis adversus - Dwyer 1970; M. daubentoni - Kokurewicz and Bartmańska 1992; Scotophilus heathi - Madhavan 1980; Nycticeius humeralis - Bain and Humphrey 1986; Vespertilio superans - Funakoshi and Uchida 1981; Tadarida pumila - McWilliam 1987a), are either polytocous or polyoestral, except $M$. daubentoni and - of species mentioned by Tuttle and Stevenson (1982) - Taphozous melanopogon and Plecotus townsendii. These cases require separate examinations.

Acknowledgements: We would like to thank Prof P. A. Racey for his comments on the manuscript. 


\section{References}

Bain J. R. and Humphrey S. R. 1986. Social organization and biased primary sex ratio of the evening bat, Nycticeius humeralis. Fla Sci. 49: 22-31.

Cranbrook Earl of and Barrett H. Q. 1965. Observations on noctule bats (Nyctalus noctula) captured while feeding. Proc. zool. Soc. Lond. 144: 1-24.

Dwyer P. D. 1970. Latitude and breeding season in a polyestrous species of Myotis. J. Mammal. 51: $405-410$.

Funakoshi K. and Uchida T. A. 1981. Feeding activity during the breeding season and postnatal growth in the Namie's frosted bat, Vespertilio superans superans. Jap. J. Ecol. 31: 66-77.

Gaisler G., Hanak V. and Dungel J. 1979. A contribution of the population ecology of Nyctalus noctula (Mammalia: Chiroptera). Acta Sc. Nat. Brno 13: 1-38.

Gebhard J. 1991. Unsere Fledermäuse. Naturhistorisches Museum Basel: 1-72.

Howes C. A. 1979. The noctule bat, Nyctalus noctula (Schr.) in Yorkshire. Naturalist 104: 31-38.

Kleiman D. G. and Racey P. A. 1969. Observations of noctule bats (Nyctalus noctula) breeding in captivity. Lynx 10: 65-77.

Kokurewicz T. and Bartmańska J. 1992. Early sexual maturity in male Daubenton's bats Myotis daubentoni (Kuhl, 1819) (Chiroptera: Vespertilionidae); field observations and histological studies on the genitalia. Myotis 30: 95-107.

Krishna A. and Dominic C. G. 1983. Growth of young and sexual maturity in three species of Indian bats. J. Anim. Morphol. Physiol. 30: 162-168.

Kronwitter F. 1988. Population structure, habitat use and activity patterns of the noctule bat, Nyctalus noctula Schreb. 1774 (Chiroptera: Vespertilionidae) revealed by radiotracking. Myotis 26: 23-85.

Kunkel G. and Taake K.-H. 1986. Beobachtungen zur Fortpflanzungsbiologie mediterraner Zwergfledermäuse (Pipistrellus pipistrellus). Z. Säugetierk. 51: 124-125.

Madhavan A. 1980. Breeding habits and associated phenomena in some Indian bats. Part VI. Scotophilus heathi (Horsefield) - Vespertilionidae. J. Bombay Natur. History 77: 227-237.

McWilliam A. 1987a. Polyoestry and postpartum oestrus in Tadarida (Chaerephon) pumila (Chiroptera: Molossidae) in northern Ghana, West Africa. J. Zool., Lond. 213: 735-768.

McWilliam A. 1987b. The reproductive and social biology of Coleura afra in a seasonal environment. [In: Recent advances in the study of bats. M. B. Fenton, P. A. Racey and J. M. V. Rayner, eds]. Cambridge Univ. Press, Cambridge: $324-350$.

Pun'utin K. K. 1970. [Ecology of bats in forest regions]. Krupskaya's Pedagogical Institute of Moscow. D. Thesis, Moscow: 1-230. [In Russian]

Racey P. A. 1974. Ageing and assessment of reproductive status of Pipistrelle bats, Pipistrellus pipistrellus. J. Zool., Lond. 173: 264-271.

Reed A. F. and Harvey P. H. 1989. Life history differences among the eutherian radiations. J. Zool., Lond. 219: 329-352.

Sluiter J. W. and van Heerdt P. F. 1966. Seasonal habits of the noctule bat (Nyctalus noctula). Arch. Neerl. Zool. 16: 423-439.

Speakman J. R. and Racey P. A. 1986. The influence of body condition on sexual development of male brown long-eared bats (Plecotus auritus) in the wild. J. Zool., Lond. A210: 515-525.

Tuttle M. L. and Stevenson D. 1982. Growth and survival of bats. [In: Ecology of bats. T. M. Kunz, ed]. Plenum Press, New York: 105-150.

Zingg P. E. 1988. Eine auffällige Lautäusserung des Abendseglers, Nyctalus noctula (Schreber) zur Paarungszeit (Mammalia: Chiroptera). Revue suisse Zool. 95: 1057-1062.

Received 14 February 1992, revised 10 January 1994, accepted 20 January 1994. 